\title{
Knowledge, Attitudes, Practices, and Determinants Towards Wastewater Management in Northwest Ethiopia: A Community-Based Cross-Sectional Study
}

\section{Gebisa Kabito \\ Henok Dagne (D) \\ Mulat G/Hiwot}

Department of Environmental and Occupational Health and Safety, Institute of Public Health, College of Medicine and Health Sciences, University of Gondar, Gondar, Ethiopia
Correspondence: Gebisa Kabito Email gebeguyasa4@gmail.com
Background: Globally, waste management has been a major public health problem. Public knowledge, attitudes, practices (KAP) and participation are key elements of any waste management program. In Ethiopia, however, the level of KAP and associated factors regarding wastewater management (WWM) at the household level are not well studied and understood. This study was, therefore, conducted to assess the knowledge, attitude, practice and associated factors of wastewater management (WWM) among the residents in Gondar town, Ethiopia.

Methods: A community-based cross-sectional study was conducted during March and April, 2016. A total of 422 participants were selected using the systematic random sampling technique. A structured questionnaire was employed to collect data which were entered and analyzed using the Statistical Package for Social Science (SPSS) version 20. A multivariable binary logistic regression analysis was used to ascertain the significance of associations at $<0.05$ p-value and the adjusted odds ratio (AOR) with a 95\% confidence interval (CI).

Results: Among 422 study participants included, $63.5 \%$, 43.4\%, and $48.6 \%$ of them had good knowledge, attitudes, and self-reported practices regarding WWM, respectively. Knowledge of participants was significantly associated with house rent (AOR 1.12, 95\% CI $(1.22,3.69)$, civil servant (AOR 5.47, 95\% CI $(1.87,8.02)$, and positive attitudes (AOR $2.69,95 \%$ CI $(1.68,4.30)$, while space availability (AOR 1.84, 95\% CI $(1.23,2.75)$, and good knowledge (AOR 2.46, 95\% CI $(1.61,3.77)$ were associated factors of attitudes. Moreover, good knowledge (AOR 1.32, 95\% CI (1.87, 2.02), and positive attitudes (AOR $1.03,95 \%$ CI $(1.01,2.34)$ were significantly associated factors of self-reported practices.

Conclusion: Limited knowledge, attitudes and practices were seen among study population. A great emphasis on improvement of knowledge, attitudes and practices towards WWM is necessary. Moreover, it would be better to qualitatively explore variables which explain the qualitative attributes of the community, like community Attitudes and knowledge.

Keywords: awareness, attitudes, determinant, knowledge, practices, wastewater, Ethiopia

\section{Introduction}

Waste management includes all activities related to the handling, treatment, disposal or recycling of waste materials. ${ }^{1,2}$ Alongside the WHO and World Bank reports, several studies have reported that the management of waste has been a major challenge globally. ${ }^{1,3-7}$ Aside from sanitation, improper household wastewater management (WWM) may have health, environmental and economic problems. ${ }^{8-10}$ The US report, for example, traces 22 diseases to improper WWM. ${ }^{11}$ Researchers also reported that inadequate WWM has contributed to the degradation of air, soil, water, 
insect and vermin spread, and to the loss of aesthetic beauty. ${ }^{7,12}$ Furthermore, the economic burden of improper WWM in Funafuti costs nearly half million dollars per year $^{13}$ and Tonga spent 5.6 million TOP annually. ${ }^{14}$

In Ethiopia, it is estimated that around $70-80 \%$ of the disease burden are preventable by improving environmental sanitation. ${ }^{15,16}$ Conversely, nearly half of the inhabitants handle household liquid waste by openly discharging it into any accessible public properties, such as streets, drainage lines and nearby open spaces. ${ }^{17,18}$

Public awareness and participation is a key element of any waste management program. ${ }^{19}$ Similarly, researchers have reported that knowledge of adverse health effects of waste is correlated with the good practice of household waste management. ${ }^{20,21}$ Although many factors could be attributed to inadequate WWM, it is essential to emphasize the role of the community, their attitudes, practices, and interactions. ${ }^{20,22}$

However, the level of KAP and the factors contributing to WWM at household level are not well studied and understood in Ethiopia. The current study is solely concerned with Wastewater management. Therefore, this study aimed to assess the level of KAP and associated factors towards WWM among residents in Gondar town, Ethiopia.

\section{Methods}

\section{Study Design and Setting}

A community-based cross-sectional study was conducted in Gondar town from March to April 2016. The town is located in the Amhara region, at a distance of $747 \mathrm{Km}$ from Addis Ababa, the capital city of Ethiopia. Gondar had 12 sub-cities and 12 urban and 10 rural kebeles, with an estimated 360,600 population and $3200 / \mathrm{km} 2$ of surface area. $^{23}$ Despite the city's numerous tourist attractions, the wastewater management capacity is limited to $24 \mathrm{~m}^{3} /$ day, but the town's production capacity exceeds 32,411m3/ day. ${ }^{24}$ At the time of this study, 51,304 households were registered. $^{25}$ Map of the study area (Figure 1).

\section{Source and Study Population}

All households in the town of Gondar were the source population, while participants selected from each households using a systematic sampling technique were the study population. Residents living in selected households as heads or any other household members $\geq 18$ years of age were included in the study and those who were unable to communicate easily during data collection were excluded.

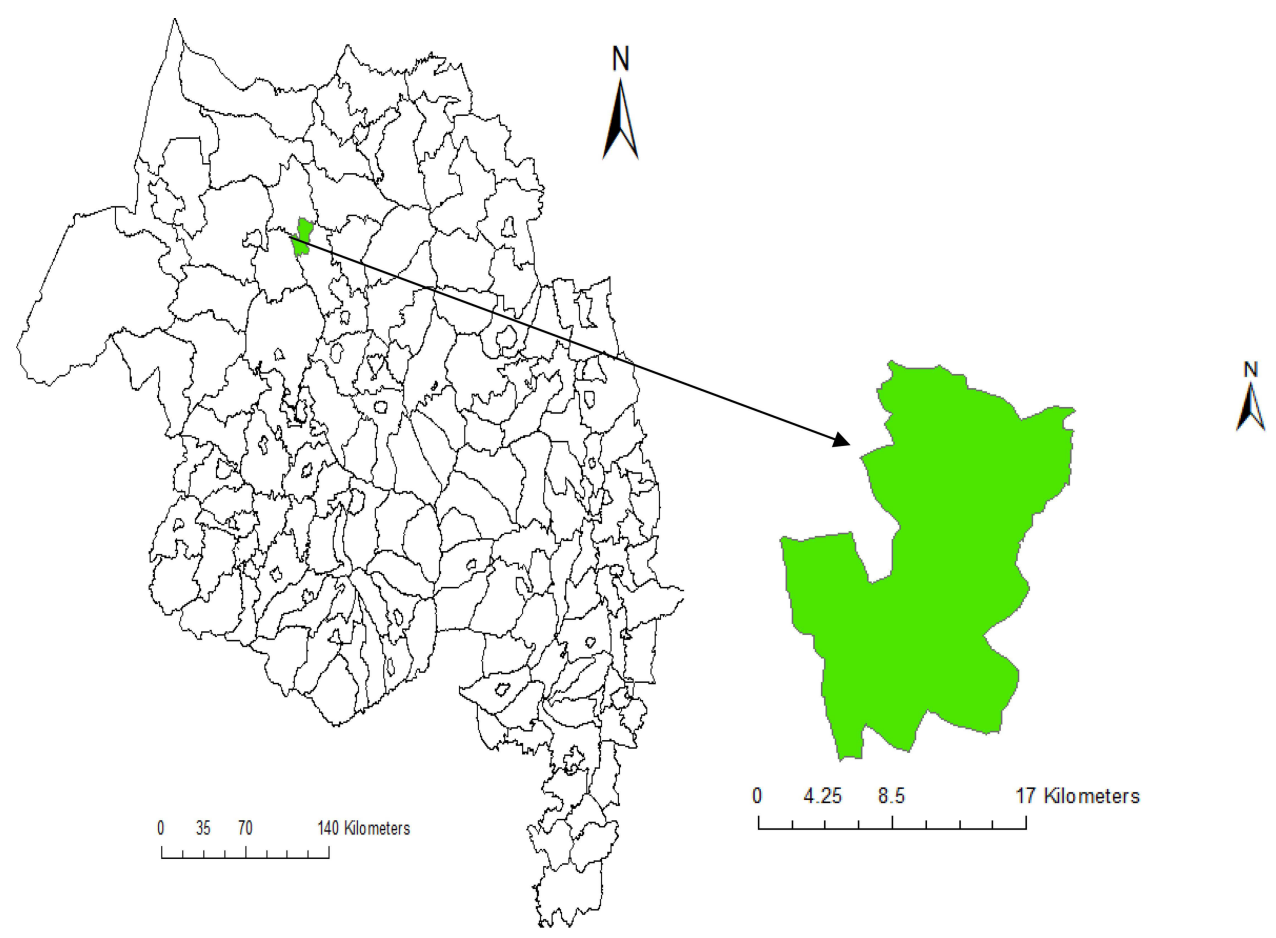

Figure I Map of the study area 2016

Notes: White: Amhara National Region, Ethiopia. Green: Gondar town 


\section{Sample Size Determination}

The single population proportion formula ${ }^{26,27}$ was used to determine the sample size with the following assumptions: $p$ (proportion of KAP assumed to be $50 \%$ since there was no previous study at the time of this study), $d$ (margin of error $=5 \%$ ) and $Z \alpha / 2$ (standard score value for $95 \%$ confidence level $=1.96$ ), the minimum sample size $(\mathrm{n})$ was 422 having considered $10 \%$ non-response rate.

\section{Data Collection Instrument and Procedures}

The data were collected using a pre-tested, structured interviewer-administered questionnaire that investigators developed after reviewing numerous literature..$^{25,28-31}$ The questionnaire consisted of four separate components. The first component of the questionnaire covered demographic information that included age, sex, and marital status, education level, occupation, and etc. The second part assessed general knowledge about WWM (Yes/No). The third part assessed the attitudes of the respondents towards WWM; and the final part covered the household's practice towards WWM. Five point Likert scale was used to assess attitude ( $5=$ strongly agree) and ( $1=$ strongly disagree) and practice was assessed by different category of questions related to WWM. Internal consistency and reliability were examined using Cronbach's alpha which were greater than 0.72 . The full survey questionnaire is provided in the Supplement 1.

A systematic sampling technique was used to select participants from the study population. Lottery method was used to select a respondent whenever more than one eligible respondent found in the selected household. The data collectors visited all of the systematically selected households and interviewed the heads or any other members of the households aged $\geq 18$ years.

\section{Data Quality Control}

All questionnaires were prepared in English and then translated into Amharic (local language) which were used for data collection and re-translated back to English. We recruited five final year Environmental Health Science students for data collection and two Environmental Health lecturers as supervisors. One day training was offered for data collectors and supervisors on topics related to research objectives, clarity of questions, the confidentiality of information and consent in the study. The questionnaires were pre-tested on 30 households that were not included in the final analysis and the relevant modifications were made before the actual data collection was conducted.

Operational definitions: Knowledge:-We calculated the mean score of the 12 items of knowledge questions and categorized as good (if participants scored $\geq$ mean score of the correctly answered questions) or poor (if participants scored $<$ mean score of the correctly answered questions). ${ }^{25}$ Attitudes:-It is measured by 17 questions. All individual answers to attitudinal questions were computed to obtain total scores; then, mean score was calculated to categorize as having good attitude (if participants scored $\geq$ mean score) or poor attitude (if Participants scored $<$ mean score). ${ }^{25}$ Selfreported practices:- It is measured by 13 questions. All individual answers to practice questions were computed to obtain total mean scores and categorized as good practice (if participants scored $\geq$ mean score) or poor practice (if participants scored $<$ mean score). ${ }^{25}$

\section{Data Management and Analysis}

The data were checked for completeness and entered into EPI info version 7 and exported to SPSS version 20 for analysis. Using a binary logistic regression analysis, we fitted each predictor variable in to a bivariate logistic regression model separately to explore associations with the dependent variable (knowledge, attitudes, and practices). Explanatory variables with p-value $<0.2$ in the bivariate analysis were exported to the multivariable logistic regression model using backward variable selection method. Hosmer and Lemeshow goodness-of-fit test was used to check the model fitness $(\mathrm{P}>0.05)$. A multi colinearity assumption was checked using Variance Inflation Factor (VIF < 5). Odds ratios (OR) with 95\% confidence intervals $(\mathrm{CI})$ and $\mathrm{p}$-value $<0.05$ were applied to establish the significance of associations.

\section{Results}

\section{Socio-Demographic Information}

A total of 422 of the 422 sampled participants responded fully to the interview, yielding a $100 \%$ response rate. Out of the respondents, $(47.9 \%)$ were male with a mean age of 34.5 years and a standard deviation of \pm 4.11 . The largest number of respondents, (28.4\%) attended secondary school grade 912 , (22.7\%) attended religious schools and $(22.5 \%)$ had technical or vocational trainings. Furthermore, almost more than half of the respondents $(58.1 \%)$ had no space to construct wastewater disposal facilities (Table 1). 
Table I Socio Demographic Characteristics of Study Participants to Assess Knowledge, Attitudes, and Self-Reported Practices and Associated Factors Towards Wastewater Management Among Residents in Gondar Town, Northwest Ethiopia, 2016

\begin{tabular}{|c|c|c|c|}
\hline $\begin{array}{l}\text { Variables } \\
(\mathrm{N}=422)\end{array}$ & Category & Number & Percent (\%) \\
\hline \multirow[t]{3}{*}{ Sex } & & & \\
\hline & Male & 202 & 47.9 \\
\hline & Female & 220 & 52.1 \\
\hline \multirow[t]{5}{*}{ Age } & & & \\
\hline & $18-20$ & 14 & 3.3 \\
\hline & $21-29$ & 135 & 32.0 \\
\hline & $30-39$ & 216 & 51.2 \\
\hline & $>40$ years & 57 & 13.5 \\
\hline \multirow[t]{6}{*}{ Religion } & & & \\
\hline & Orthodox & 203 & 48.1 \\
\hline & Muslim & 145 & 34.4 \\
\hline & Protestant & 40 & 9.5 \\
\hline & Catholic & 15 & 3.6 \\
\hline & Others & 19 & 4.5 \\
\hline \multirow[t]{9}{*}{$\begin{array}{l}\text { Educational } \\
\text { status }\end{array}$} & & & \\
\hline & Cannot read and write & 2 & 0.5 \\
\hline & Read only & 5 & 1.2 \\
\hline & Religious schooling & 96 & 22.7 \\
\hline & Read and write & 26 & 6.2 \\
\hline & Primary education (I-8) & 30 & 7.1 \\
\hline & Secondary $(9-12)$ & 120 & 28.4 \\
\hline & Technical and & 96 & 22.7 \\
\hline & Higher education & 48 & 11.4 \\
\hline \multirow[t]{3}{*}{ Family size } & & & \\
\hline & $1-5$ & 284 & 67.3 \\
\hline & Greater than 5 & 138 & 32.7 \\
\hline \multirow[t]{6}{*}{ Occupation } & & & \\
\hline & Student & 40 & 9.5 \\
\hline & Unemployed & 33 & 7.8 \\
\hline & Self employed & 229 & 54.3 \\
\hline & Civil servant & 90 & 21.3 \\
\hline & Retired & 30 & 7.1 \\
\hline \multirow[t]{5}{*}{ Income } & & & \\
\hline & $\begin{array}{l}\text { Less than } 500 \mathrm{ETB} / \\
\text { month }\end{array}$ & 48 & $1 \mathrm{I} .4$ \\
\hline & $50 \mathrm{I}-1000 \mathrm{ETB} / \mathrm{month}$ & 105 & 24.9 \\
\hline & Greater than 1000 & 269 & 63.7 \\
\hline & ETB/month & & \\
\hline \multirow[t]{3}{*}{ Tenure } & & & \\
\hline & Owner & 302 & 71.6 \\
\hline & Renter & 120 & 28.4 \\
\hline
\end{tabular}

(Continued)
Table I (Continued)

\begin{tabular}{|l|l|l|l|}
\hline $\begin{array}{l}\text { Variables } \\
\mathbf{( N = 4 2 2 )}\end{array}$ & Category & Number & Percent (\%) \\
\hline $\begin{array}{l}\text { Space } \\
\text { availability }\end{array}$ & & & \\
& Have space & 177 & 41.9 \\
& Have no space & 245 & 58.1 \\
\hline Marital & & & \\
status & & & \\
& Single & 93 & 22.0 \\
& Married & 279 & 66.1 \\
& Divorced & 20 & 4.7 \\
& Widowed & 30 & 7.1 \\
\hline
\end{tabular}

\section{Level of Knowledge, Attitudes, and Self-Reported Practices of Respondents Towards WWM}

It was found that the mean knowledge score was 9.84 (S.D 1.29). Most of the respondents had good knowledge of WWM, 63.5\%, 95\% CI $(59,68)$. The mean attitudes along with the standard deviation was 12.52 (SD 3.16). Above half $(56.6 \%)$ of study participants had poor attitudes with $95 \%$ CI $(47.2,58.3)$. The mean value of the self-reported practices together with the standard deviation was 8.45 (SD 2.31). Among the study population (51.4\%), 95\% CI $(44,54)$ had poor self-reported WWM practices.

\section{Factors Associated with Participant's Knowledge Level}

Housing tenure, occupational status, and attitude were significantly associated with knowledge in the multivariable regression analysis. Accordingly, as compared with the participants who owned the house, the probability of a good level of knowledge among participants who rent the house was 1.12 times higher [AOR: $1.12 ; 95 \% \mathrm{CI}(1.22,3.69)$ ]. The odds of good knowledge were 5.47 times higher [AOR: 5.47; 95\% CI $(1.87,8.02)]$ among respondents who were civil servant than those who were retired by their occupational status. The probability of good knowledge was 2.69 times higher [AOR: $2.69 ; 95 \% \mathrm{CI}:(1.68,4.30)]$ among participants who had a good level of attitude towards WWM (Table 2).

\section{Factors Associated with Participant's Attitudes Level}

In the multivariable regression analysis space availability for disposal [(AOR: 1.84; 95\% CI $(1.23,2.75)]$ and 
Table 2 Factors Associated with Knowledge Level Among Residents in Gondar Town, Northwest Ethiopia, 2016

\begin{tabular}{|c|c|c|c|c|c|}
\hline \multirow[t]{2}{*}{ Variables $(\mathrm{N}=422)$} & \multicolumn{2}{|c|}{ Knowledge Level } & \multirow[t]{2}{*}{ COR $(95 \% \mathrm{Cl})$} & \multirow[t]{2}{*}{ AOR $(95 \% \mathrm{Cl})$} & \multirow[t]{2}{*}{$p$-value } \\
\hline & Poor n (\%) & Good n (\%) & & & \\
\hline \multicolumn{6}{|l|}{ Age } \\
\hline Less than 20 & $5(3.2 \%)$ & 9 (3.4\%) & $1.51(0.45,5.06)$ & $1.05(0.47,8.01)$ & 0.092 \\
\hline 21 to 29 & $56(36.4 \%)$ & 79 (29.5\%) & $1.18(0.63,2.21)$ & $1.06(0.75,3.67)$ & 0.923 \\
\hline $30-39$ & $67(43.5 \%)$ & 149 (55.6\%) & $1.87(1.03,3.38)$ & $1.40(1.02,3.93)$ & 0.082 \\
\hline Above 40 & $26(16.9 \%)$ & 31 (II.6\%) & 1 & 1 & \\
\hline \multicolumn{6}{|l|}{ Marital status } \\
\hline Single & $45(29.2 \%)$ & $48(17.9 \%)$ & 1 & I & \\
\hline Married & $84(54.5 \%)$ & 195 (72.8\%) & $2.18(1.35,3.52)$ & $2.00(1.09,4.35)$ & 0.091 \\
\hline Divorced & $10(6.5 \%)$ & $10(3.7 \%)$ & $0.94(0.36,2.46)$ & $\mathrm{I} .44(0.44,4.74)$ & 0.553 \\
\hline Widowed & $15(9.7 \%)$ & $15(5.6 \%)$ & $0.94(0.41,2.14)$ & $1.08(0.37,3.13)$ & 0.892 \\
\hline \multicolumn{6}{|l|}{ Average monthly income (ETB) } \\
\hline$\leq 500$ & $24(15.6 \%)$ & $24(9.0 \%)$ & I & I & \\
\hline $501-1000$ & $40(26.0 \%)$ & $65(24.3 \%)$ & $1.625(0.82,3.24)$ & $2.20(0.97,5.00)$ & 0.060 \\
\hline$>1000$ & 90 (58.4\%) & 179 (66.8\%) & $1.99(1.07,3.70)$ & $2.21(0.98,4.97)$ & 0.061 \\
\hline \multicolumn{6}{|l|}{ Housing tenure } \\
\hline Owner & 117 (76.0\%) & 185 (69.0\%) & I & I & \\
\hline Renter & $37(24.0 \%)$ & $83(31.0 \%)$ & $1.42(0.90,2.23)$ & $1.12(1.22,3.69)^{*}$ & 0.001 \\
\hline \multicolumn{6}{|l|}{ Space availability } \\
\hline Have space & $55(35.7 \%)$ & 123 (45.9\%) & $1.53(1.02,2.30)$ & $1.24(0.75,2.03)$ & 0.403 \\
\hline Have no space & 99 (64.3\%) & 145 (54.1\%) & I & I & \\
\hline \multicolumn{6}{|l|}{ Occupation } \\
\hline Civil servant & $24(15.6 \%)$ & 66 (24.6\%) & $6.42(2.58,15.94)$ & $5.47(1.87,8.02)^{*}$ & 0.002 \\
\hline Self-employed & 79 (5I.3\%) & 150 (56.0\%) & $4.43(1.94,10.13)$ & $3.16(0.95,7.99)$ & 0.09 \\
\hline Unemployed & 13 (8.4\%) & $20(7.5 \%)$ & $3.59(1.26,10.23)$ & $3.20(0.94,10.96)$ & 0.064 \\
\hline Student & 17 (II.0\%) & $23(8.6 \%)$ & $3.157(1.16,8.59)$ & $4.58(1.32,15.90)$ & 0.061 \\
\hline Retired & $21(13.6 \%)$ & $9(3.4 \%)$ & 1 & 1 & \\
\hline \multicolumn{6}{|l|}{ Attitudes } \\
\hline Poor & 109 (70.8\%) & 130 (48.5\%) & I & I & \\
\hline Good & $45(29.2 \%)$ & $138(51.5 \%)$ & $2.57(1.69,3.92)$ & $2.69(1.68,4.30)^{*}$ & 0.0001 \\
\hline \multicolumn{6}{|l|}{ Practices } \\
\hline Poor & $87(56.5 \%)$ & I 30 (48.5\%) & I & I & \\
\hline Good & $67(43.5 \%)$ & 138 (51.5\%) & $1.38(0.93,2.05)$ & $1.26(0.81,1.96)$ & 0.301 \\
\hline
\end{tabular}

Notes: *Significant in multivariate logistic regression analysis. Hosmer and Lemeshow test $=0.82 \mathrm{I}$ showed that the model fitted well.

Abbreviations: AOR, adjusted odds ratio; COR, crude odds ratios; ETB, Ethiopian Birr, n, number.

good knowledge [(AOR: 2.46; 95\% CI $(1.61,3.77)]$ were significantly associated with good attitudes (Table 3).

\section{Factors Associated with Participants Practices Level}

Good knowledge [(AOR: 1.32, 95\% CI: $(1.87,2.02)]$ and positive attitudes [(AOR: $1.03,95 \% \mathrm{CI}:(1.01,2.34)]$ were significantly associated factors with self-reported practice (Table 4).

\section{Discussion}

About $63.5 \%$ of those interviewed had good WWM knowledge. This result was lower than the study in other parts of Ethiopia (81.8\%). ${ }^{32}$ This difference might be due to the participants' educational level, study time and period, sample size, and differences in the sanitation levels of the towns.

This study demonstrated that $43.4 \%$ had good attitudes to WWM. This result was lower than studies in Ethiopia $(76.9 \%),{ }^{32}$ Pakistan $(95 \%),{ }^{33}$ and India $(93.8 \%) .{ }^{34}$ The 
Table 3 Factors Associated with Attitudes Among Residents in Gondar Town, Northwest Ethiopia, 2016

\begin{tabular}{|c|c|c|c|c|c|}
\hline \multirow[t]{2}{*}{ Variables $(\mathrm{N}=422)$} & \multicolumn{2}{|c|}{ Attitudes Level } & \multirow[b]{2}{*}{$\begin{array}{l}\text { COR }(95 \% \mathrm{CI}) \text { AOR }(95 \% \\
\text { CI) p-value }\end{array}$} & \multirow[b]{2}{*}{$\begin{array}{l}\text { COR }(95 \% \text { CI) AOR }(95 \% \\
\text { CI) p-value }\end{array}$} & \multirow[b]{2}{*}{$\begin{array}{l}\text { p-value AOR }(95 \% \mathrm{CI}) \\
\text { p-value }\end{array}$} \\
\hline & Poor $\mathbf{n}$ & Goodn & & & \\
\hline \multicolumn{6}{|l|}{ Marital status } \\
\hline Single & 62 & 31 & 1 & 1 & \\
\hline Married & 148 & $13 \mid$ & $1.77(1.08,2.89)$ & $1.34(1.71,2.50)$ & 0.062 \\
\hline Divorced & 15 & 5 & $0.67(0.22,2.00)$ & $0.7 \mathrm{I}(0.2 \mathrm{I}, 2.38)$ & 0.580 \\
\hline Widowed & 14 & 16 & $2.29(0.99,5.28)$ & $2.40(0.91,6.33)$ & 0.077 \\
\hline \multirow{2}{*}{\multicolumn{6}{|c|}{$\begin{array}{l}\text { Average monthly } \\
\text { income in ETB }\end{array}$}} \\
\hline & & & & & \\
\hline$\leq 500$ & 26 & 22 & $1.00(0.54,1.86)$ & $0.99(0.5 \mathrm{I}, \mathrm{I} .82)$ & 0.060 \\
\hline $501-1000$ & 67 & 38 & $0.67(0.423,1.07)$ & $0.36(0.65,1.10)$ & 0.063 \\
\hline$>1000$ & 146 & 123 & 1 & 1 & \\
\hline \multicolumn{6}{|l|}{ Family size } \\
\hline $1-5$ & 173 & 110 & I & I & \\
\hline$>5$ & 66 & 73 & $1.74(1.16,2.62)$ & I.4I (I.9I, 2.2I) & 0.07 \\
\hline \multicolumn{6}{|l|}{ House } \\
\hline Owner & 164 & 138 & $1.40(0.91,2.16)$ & $\mathrm{I} .20(0.7 \mathrm{I}, 2.0 \mathrm{I})$ & 0.501 \\
\hline Renter & 75 & 45 & 1 & 1 & \\
\hline \multicolumn{6}{|l|}{ Space availability } \\
\hline Have space & 84 & 94 & $1.95(1.32,2.89)$ & $\mathrm{I} .84(\mathrm{I} .23,2.75)^{*}$ & 0.0001 \\
\hline Have no space & 155 & 89 & 1 & 1 & \\
\hline \multicolumn{6}{|l|}{ Occupation } \\
\hline Civil servant & 53 & 37 & $1.92(0.77,4.78)$ & $0.95(0.36,2.53)$ & 0.25 \\
\hline Self-employed & 120 & 109 & $2.50(1.07,5.84)$ & $1.66(0.68,4.04)$ & 0.256 \\
\hline Unemployed & 17 & 16 & $2.59(0.90,7.46)$ & I.9I $(0.64,5.7 I)$ & 0.248 \\
\hline Student & 27 & 13 & $1.32(0.47,3.77)$ & $1.0(0.34,3.02)$ & 0.978 \\
\hline Retired & 22 & 8 & I & I & \\
\hline \multicolumn{6}{|l|}{ Knowledge } \\
\hline Poor & 109 & 45 & I & 1 & \\
\hline Good & 130 & 138 & $2.57(1.69,3.92)$ & $2.46(\mathrm{I} .6 \mathrm{I}, 3.77)^{*}$ & 0.00001 \\
\hline \multicolumn{6}{|l|}{ Practices } \\
\hline Poor & 124 & 93 & 1 & 1 & \\
\hline Good & 115 & 90 & I.04 (0.7I, I.53) & $0.91(0.60,1.38)$ & 0.662 \\
\hline
\end{tabular}

Notes: *Significant in multivariate logistic regression analysis. Hosmer and Lemeshow test $=0.94 \mathrm{I}$ showed that the model fitted well.

Abbreviations: AOR, adjusted odds ratio; COR, crude odds ratios; ETB, Ethiopian Birr; n, number.

disparity could be influenced by cultural differences and the way waste is managed in the towns, sample sizes, data collection methods and study periods.

The present study found that $51.4 \%$ of participants reported poor WWM practices. This finding was consistent with a study in Pakistan $(52.0 \%) .{ }^{33}$ This could be due to comparable socio-economic status, developing countries could experience similar waste management practices.
In the current study, the ownership status of houses was linked to the level of knowledge. Indonesian report found a similar outcome. ${ }^{35}$ One possible explanation could be that people living in their own homes could offer concern and try to correct the waste they produce from their own homes and handle it properly.

We also found a significant association of participants' attitudes and levels of knowledge. Another study supported this. ${ }^{33}$ Persons with a positive attitude about 
Table 4 Factors Associated with Self-Reported Practices Among the Residents in Gondar Town, Northwest Ethiopia, 2016

\begin{tabular}{|c|c|c|c|c|c|}
\hline \multirow[t]{2}{*}{ Variables $(\mathrm{N}=422)$} & \multicolumn{2}{|c|}{ Practices level } & \multirow[b]{2}{*}{ COR $(95 \% \mathrm{Cl})$} & \multirow[b]{2}{*}{ AOR (95\% Cl) } & \multirow[b]{2}{*}{$p$-value } \\
\hline & Poor (n) & Good (n) & & & \\
\hline \multicolumn{6}{|l|}{ Marital status } \\
\hline Single & 49 & 44 & I & 1 & \\
\hline Married & 139 & 140 & $1.12(0.70,1.79)$ & $1.10(0.11,1.52)$ & 0.063 \\
\hline Divorced & 15 & 5 & $0.37(0.13,1.11)$ & $0.36(0.11,1.10)$ & 0.076 \\
\hline Widowed & 14 & 16 & $1.27(0.56,2.90)$ & $1.22(0.56,2.93)$ & 0.758 \\
\hline \multicolumn{6}{|l|}{ Family size } \\
\hline $\mathrm{I}-5$ & 150 & 133 & I & I & \\
\hline$>5$ & 67 & 72 & $1.21(0.81,1.82)$ & $1.01(0.65,1.58)$ & 0.961 \\
\hline \multicolumn{6}{|l|}{ Housing tenure } \\
\hline Owner & 158 & 144 & I & 1 & \\
\hline Renter & 59 & 61 & $1.13(0.74,1.73)$ & $1.13(0.73,1.75)$ & 0.677 \\
\hline \multicolumn{6}{|l|}{ Space availability } \\
\hline Have space & 85 & 93 & $1.29(0.88,1.90)$ & $1.19(0.77,1.83)$ & 0.444 \\
\hline Have no space & 132 & 112 & I & 1 & \\
\hline \multicolumn{6}{|l|}{ Knowledge } \\
\hline Poor & 87 & 67 & 1 & 1 & \\
\hline Good & 130 & 138 & $1.38(0.93,2.05)$ & I.32 (I.87, 2.02)* & 0.0001 \\
\hline \multicolumn{6}{|l|}{ Occupation/job } \\
\hline Civil servant & 42 & 48 & $1.97(0.84,4.62)$ & $1.96(1.01,4.59)$ & 0.480 \\
\hline Self-employed & 118 & 111 & $1.63(0.74,3.57)$ & $1.57(0.72,3.50)$ & 0.121 \\
\hline Unemployed & 15 & 18 & $2.07(0.76,5.69)$ & $1.97(0.70,5.50)$ & 0.253 \\
\hline Student & 23 & 17 & $1.28(0.48,3.37)$ & $1.23(0.46,3.29)$ & 0.198 \\
\hline Retired & 19 & II & I & I & \\
\hline \multicolumn{6}{|l|}{ Attitudes } \\
\hline Poor & 124 & 115 & I & 1 & \\
\hline Good & 93 & 90 & $\mathrm{I} .04(0.7 \mathrm{I}, \mathrm{I} .53)$ & $\mathrm{I} .03(\mathrm{I} .0 \mathrm{I}, 2.34)^{*}$ & 0.001 \\
\hline
\end{tabular}

Notes: *Significant in multivariate logistic regression analysis. Hosmer and Lemeshow test $=0.673$ showed that the model fitted well.

Abbreviations: AOR, adjusted odds ratio; COR, crude odds ratios, $n$, number.

human health and environmental consequences as a result of proper waste management can often handle waste from home and the nearby.

This study also showed that occupational status was associated with knowledge level of study participants. This was comparable to other findings. ${ }^{36,37}$ Community members employed by the government may usually have access to information on the variety of WWM laws and regulations available and are likely to have more knowledge of WWM than other working groups.

In the current study, resident attitudes were correlated with the level of knowledge, as indicated by previous work. $^{33,34,38}$ It could be suggested that good knowledge would lead to good attitudes towards waste handling and management measures. ${ }^{39}$
Space availability was another factor that significantly associated with attitudes. Similar results were found in past studies. ${ }^{31,40}$ Having appropriate places to treat, dispose or discharge the wastes generated could likely affect community attitudes towards managing liquid wastes.

This study found that the respondents' level of knowledge was related to the practices. Similar to previous reports. $^{32,38}$ One possible explanation could be that participants with good knowledge could understand the potential health and environmental impact of improper waste management practices.

Our study revealed that a community's attitudes was associated with good practice. ${ }^{38}$ It is reasonable that the positive feelings of people about the ultimate fate of waste generated from each home could contribute to the proper practices of WWM. 


\section{Conclusions}

Overall, knowledge, attitudes, and self-reported practices were limited. Occupational status, housing tenure, and attitudes were identified as the factors having significant association with good knowledge level of residents. Availability of space and good knowledge were identified as factors that have associations to a good level of attitude. Good knowledge and good attitude were identified as factors that contributed significantly to respondents' good practices. Therefore, it's important to improve good knowledge, positive attitudes, and good practices.

\section{Limitations of the Study}

Finally, this study was limited by its cross-sectional design that prevented causality determination. Another limitation was that we did not include direct practical observations. Thus, there might be a bias of social desirability. Also, the tool we used in this study was not a standard.

\section{Abbreviations}

AOR, adjusted odds ratio; CI, confidence interval; COR, crude odds ratio; ETB, Ethiopian Birr; KAP, Knowledge, Attitude and Practice; Km, Kilometers; $\mathrm{km}^{2}$, Square kilometer WWM, Wastewater Management; SPSS, Statistical Package for Social Science.

\section{Data Sharing Statement}

Most of the data generated during this study are included in this published article and additional data will be made available upon request to the corresponding author.

\section{Ethics Approval and Consent to Participate}

Ethical approval was obtained from the ethical committee of the Department of Environmental and Occupational Health \& Safety, College of Medicine and Health Sciences, University of Gondar. Participants were informed about the objective of the research by data collectors. Written informed consent was obtained from each study participant. To keep privacy of the information obtained, only aggregate data were used for analysis and interpretations of the results. There were no risks due to participation in this research project. The collected data were used for this research purpose only and kept with complete confidentiality. The study was conducted in accordance with the Declaration of Helsinki.

\section{Consent for Publication}

All participants provided written informed consent to publish this study.

\section{Acknowledgments}

The authors are pleased to acknowledge data collectors, field supervisors, study participants, the University of Gondar and staffs of Gondar city administration for their frank contributions to the success of this study.

\section{Author Contributions}

All authors made substantial contributions to conception and design, acquisition of data, or analysis and interpretation of data; took part in drafting the article or revising it critically for important intellectual content; agreed to submit to the current journal; gave final approval of the version to be published; and agreed to be accountable for all aspects of the work.

\section{Funding}

The authors of this study did not receive funds from any funding institution. However, University of Gondar covered questionnaire duplication fees.

\section{Disclosure}

The authors declare that they have no competing interests in this work.

\section{References}

1. Adogu POU, Uwakwe KA, Egenti NB, Okwuoha A, Nkwocha IB. Assessment of waste management practices among residents of Owerri Municipal Imo State Nigeria. J Environ Prot (Irvine, Calif). 2015;6 (05):446-456. doi:10.4236/jep.2015.65043

2. Pongrácz E, Pohjola VJ. Re-defining waste, the concept of ownership and the role of waste management. Resour Conserv Recycl. 2004;40 (2):141-153. doi:10.1016/S0921-3449(03)00057-0

3. De Bruijne G, Geurts M, Appleton B Sanitation for all?: IRC International Water and Sanitation Centre Delft; 2007.

4. Handzel T. Water, Sanitation, and Hygiene (WASH). In: Health in Humanitarian Emergencies: Principles and Practice for Public Health and Healthcare Practitioners. 2018:136.

5. Rouse M. The worldwide urban water and wastewater infrastructure challenge. Int J Water Resour Dev. 2014;30(1):20-27. doi:10.1080/ 07900627.2014.882203

6. Programme UNE. Global Waste Management Outlook. UN; 2016.

7. Cheever M. Waste management in Ethiopia. In: Environmental Policy Review; 2011.

8. Beyene A, Hailu T, Faris K, Kloos H. Current state and trends of access to sanitation in Ethiopia and the need to revise indicators to monitor progress in the Post-2015 era. BMC Public Health. 2015;15 (1):451. doi:10.1186/s12889-015-1804-4

9. World Health Organization. Safer water, better health: costs, benefits and sustainability of interventions to protect and promote health. 2008. Avaliable from: https://apps.who.int/iris/bitstream/handle/10665/ 43840/9789241596435_eng.pdf. Accessed 25 December 2018. 
10. Water Supply and Sanitation Directorate. Urban wastewater management strategy; 2017. Available from: https://www.cmpethiopia.org/ content/download/2741/11355/file/FINAL\%20UWWMS.pdf. Accessed 25 January 2018.

11. Osei FB, Duker AA. Spatial dependency of V. cholera prevalence on open space refuse dumps in Kumasi, Ghana: a spatial statistical modelling. Int $J$ Health Geogr. 2008;7(1):62. doi:10.1186/1476072X-7-62

12. Hounkpe S, Adjovi E, Crapper M, Awuah E. Wastewater Management in Third World Cities: case Study of Cotonou, Benin. J Environ Prot (Irvine, Calif). 2014;5(05):387-399. doi:10.4236/ jep.2014.55042

13. Lal P, Saloa K, Uili F. Economics of liquid waste management in Funafuti. Tuvalu, IWP-Pacific Technical Report; 2006;36.

14. Lal PN, Takau L. Economic Costs of Waste in Tonga. SPREP; 2006.

15. Ashford R. The ecology of health and disease in Ethiopia. Trans $R$ Soc Trop Med Hyg. 1995;89(2):239. doi:10.1016/0035-9203(95) 90517-0

16. Kumie A, Ali A. An overview of environmental health status in Ethiopia with particular emphasis to its organization, drinking water and sanitation: a literature survey. Ethiop J Health Dev. 2005;19 (2):89-103. doi:10.4314/ejhd.v19i2.9977

17. Mengistie B, Baraki N. Community based assessment on household management of waste and hygiene practices in Kersa Woreda, Eastern Ethiopia. Ethiop $J$ Health Dev. 2010;24(2):103-109. doi:10.4314/ejhd.v24i2.62958

18. Mohammed A, Zungu L, Hoque ME. Wastewater and solid waste disposal patterns of Dukem town households in Ethiopia. $S$ Afr $J$ Infect Dis. 2013;28(2):106-111. doi:10.1080/10158782.2013. 11441528

19. Hasan SE. Public awareness is key to successful waste management. $J$ Environ Sci Health A. 2004;39(2):483-492. doi:10.1081/ESE120027539

20. Okechukwu O, Okechukwu A, Noye-Nortey H, Agyei O. Health perception of indiscriminate waste disposal - a Ghanaian case study. $J$ Med Med Sci. 2012;3(3):146-154.

21. Aroj B, Muhammad M, Ushahid A, Qasim M. Epidemiology impact of solid waste and assessment of awareness level among rural areas of Pakistan. Am Eurasian J Agric Environ Sci. 2004;14(9):831-837.

22. Ojewale OS. Intraurban analysis of domestic solid waste disposal methods in a sub-sahara African city. $J$ Waste Manag. 2014;2014:1-7. doi:10.1155/2014/193469

23. Belachew H, Assefa Y, Guyasa G, et al. Sick building syndrome and associated risk factors among the population of Gondar town, northwest Ethiopia. Environ Health Prev Med. 2018;23(1):54. doi:10. 1186/s12199-018-0745-9

24. Ministry of Water Irrigation and Energy. Urban wastewater management strategy. Available from: file://C:/Users/Hp/Desktop/occupa tional $\% 20$ diseases/Draft $\% 20$ final $\% 20$ wastewater $\% 20$ management $\%$ 20strategy,\%20Feb\%202015.pdf. Accessed May 22, 2016. 2015.

25. Situational Analysis of Urban Sanitation and Waste Management; 2015. Available from: https://publications.jsi.com/JSIInternet/Inc/ Common/_download_pub.cfm?id=15883\&lid=3. Accessed 2016.
26. Charan J, Biswas T. How to calculate sample size for different study designs in medical research? Indian J Psychol Med. 2013;35 (2):121-126. doi:10.4103/0253-7176.116232

27. Lwanga SK, Lemeshow S; World Health Organization. Sample Size Determination in Health Studies: A Practical Manual. 1991.

28. Emanuel E. Wastewater management in the wider Carribean region: knowledge, attitudes and practice (KAP) study. In: Carribean: Carribean Regional Fund for Wastewater Management; 2010 :1-49.

29. Kwagala R. Knowledge, Attitude and Practices of Kasokoso Community Members Towards Solid Waste Management. International Health Sciences University; 2016.

30. Faris K, Alemayehu T Humanand other liquid waste management. 2013.

31. Mekonnen FH. Liquid waste management: the case of Bahir Dar, Ethiopia. Ethiop J Health Dev. 2012;26(1):49-53.

32. Yemaneh Y, Abera T, Hailu D, et al. Knowledge attitude and practice towards solid and liquid waste management among Addis ketema and Kometa kebele community Mizan-Aman town, Bench-Maji zone, South Nations Nationalities and Peoples Regional State, South West Ethiopia, 2017. J Environ Geol. 2017;1(1):17-21. doi:10.4172/25917641.1000005

33. Shahzadi A, Hussain M, Afzal M, Sa G. Determination the level of knowledge, attitude, and practices regarding household waste disposal among people in rural community of Lahore. J Soc Sci Manag. 2018;5(3):219-224.

34. Kaithery NN, Karunakaran UJ. Study on attitude of household waste management in a rural area of Northern Kerala. J Commun Med Public Health. 2019;6(5):2095-2102.

35. Gusti A. The relationship of knowledge, attitudes, and behavioral intentions of sustainable waste management on primary school students in city of Padang, Indonesia. J Appl Environ Sci. 2016;11 (5):1323-1332.

36. Naing YH, Somrongthong R. Factors influnencing the practice of household waste management among myanmar migrants in Muang District, Ranong Province, Thailand. J Health Res. 2010;24(Suppl. 2):65-70.

37. Almasi A, Mohammadi M, Azizi A, et al. Assessing the knowledge, attitude and practice of the kermanshahi women towards reducing, recycling and reusing of municipal solid waste. Resour Conserv Recycl. 2019;141:329-338. doi:10.1016/j.resconrec.2018.10.017

38. Jatau AA. Knowledge, attitudes and practices associated with waste management in Jos South Metropolis, Plateau State. Mediterr J Soc Sci. 2013;4(5):119.

39. Mamady K. Factors influencing attitude, safety behavior, and knowledge regarding household waste management in Guinea: a cross-sectional study. J Environ Public Health. 2016;2016:1-9. doi:10.1155/2016/9305768

40. Mugambi P, Gichuki N, Management P. Factors influencing house hold functional solid waste management in Meru town, Meru County, Kenya; 2017: 141-160.
Risk Management and Healthcare Policy is an international, peerreviewed, open access journal focusing on all aspects of public health, policy, and preventative measures to promote good health and improve morbidity and mortality in the population. The journal welcomes submitted papers covering original research, basic science, clinical \& epidemiological studies, reviews and evaluations, guidelines, expert opinion and commentary, case reports and extended reports. The manuscript management system is completely online and includes a very quick and fair peer-review system, which is all easy to use. Visit http://www.dovepress.com/testimonials.php to read real quotes from published authors. 